\title{
Analisis Pendapatan dan Risiko Usaha Tani Udang Windu di Kelurahan Belawan Sicanang Kecamatan Medan Belawan
}

\author{
Surya Sevi Wijayanna Tobing ${ }^{*}$ \\ Satia Negara Lubis ${ }^{2}$ \\ Rulianda P. Wibowo ${ }^{3}$ \\ ${ }^{1}$ Mahasiswa Magister Agribisnis Fakultas Pertanian Universitas Sumatera Utara, Indonesia \\ 2,3Dosen Magister Agribisnis Fakultas Pertanian Universitas Sumatera Utara, Indonesia \\ *email: suryawijayana31@gmail.com \\ Diterima: Agustus 2020; Disetujui: Desember 2020; Dipublish: April 2021
}

\begin{abstract}
Abstrak
Usahatani udang windu merupakan usaha yang memiliki potensi yang besar karena harga jual yang cenderung stabil. Penelitian ini bertujuan untuk mengetahui pendapatan usahatani udang windu, untuk mengetahui risiko produksi, harga dan pendapatan usahatani udang windu. Penelitian dilakukan di Kelurahan Belawan Sicanang Kecamatan Medan Belawan Kota Medan. Jumlah sampel sebanyak 30 petambak. Analisis data menggunakan analisis kualitatif dan kuantitatif. Hasil penelitian menunjukkan bahwa keuntungan yang diperoleh setiap musim tanam sebesar Rp. 3.038.955/ha/ musim tanam. Analisis risiko produksi menunjukkan bahwa koefisien variasi produksi sebesar 0,19 dengan batas bawah sebesar 49,99. Analisis risiko harga menunjukkan bahwa koefisien variasi harga sebesar 0,19 dengan batas bawah sebesar 58.051. Analisis risiko pendapatan menunjukkan bahwa koefisien variasi pendapatan sebesar 0,48 dengan batas bawah sebesar 124.489 dari hasil tersebut menunjukkan bahwa petambak udang windu tidak mengalami risiko terhadap produksi, harga dan pendapatan.
\end{abstract}

Kata Kunci: Pendapatan, Udang, Risiko, Produksi, Harga

\begin{abstract}
The breeding of black tiger shrimp is the breeding which has the profitable potential because of the selling price which constantly stable. This research is aim to discover the income of black tiger shrimp breeding, production risk, the price and the income of black tiger shrimp. The research has carried out in Belawan Sicanang Urban Village Medan Belawan Sub-district Medan City. There are 30 ponds. The analysis is using qualitative and quantitative method. The result of the analysis is showing that the income obtained Rp. 3.038.955/ha from every growing season. The analysis of risk production shows that the coefficient of price variation in the amount of 0,19 with the lower limit is 58.051. The Risk analysis shows that the coefficient of price in the amount of 0,48 with the lower limit 124.489 from the results show that the farm of black tiger shrimp not get impacted of the production, price and income.
\end{abstract}

Keywords: Income, Shrimp, Risk, Production, Rice

\section{PENDAHULUAN}

Sumatera Utara merupakan provinsi kedua terbesar penghasil udang di Indonesia dengan produksi 185.591 ton setelah Jawa Timur. Produksi perikanan budidaya terdiri budidaya tambak 20.000 Ha dan budidaya laut $100.000 \mathrm{Ha}$, budidaya air tawar 81.372,84 Ha dan perairan umum $155.797 \mathrm{Ha}$, kawasan pesisir Sumatera Utara mempunyai panjang pantai $1300 \mathrm{~km}$ yang terdiri dari panjang pantai timur $545 \mathrm{~km}$, panjang pantai barat $375 \mathrm{~km}$ dan Kepulauan Nias dan pulau-pulau baru sepanjang $350 \mathrm{Km}$ (Badan Pusat Statistik, 2017).

Kota Medan merupakan salah satu tempat budidaya udang terbesar ketiga setelah Kabupaten Langkat dan Batubara di Provinsi Sumatera Utara. Kota Medan 
menghasilkan udang sebesar 1.232 ton Tahun 2017 (Badan Pusat Statistik, 2018). Tiga kecamatan dari Kota Medan merupakan daerah pesisir sehingga dapat melakukan budidaya tambak udang, daerah tersebut adalah Kecamatan Medan Labuhan, Medan Belawan dan Medan Marelan.

Kelurahan Belawan Sicanang merupakan salah satu kelurahan yang ada di Kecamatan Medan Belawan. Kelurahan Belawan Sicanang salah satu sentra produksi udang windu di Kecamatan Medan Belawan. Masyarakat membudidayakan udang windu karena udang windu adalah udang asli Indonesia yang memiliki harga dan permintaan udang cenderung stabil serta kandungan gizi udang tinggi. Petambak udang windu di Kelurahan Belawan Sicanang membudidayakan udang windu dengan sistem ekstensif (alam) (Kantor Lurah Belawan Sicanang, 2019).

Petambak udang windu di Kelurahan Belawan Sicanang menerapkan sistem budidaya udang windu yang disarankan pemerintah tertuang dalam Pedoman Umum Pembesaran Udang Windu dan Udang Vaname dalam Peraturan Menteri Kelautan dan Perikanan Republik Indonesia Nomor 75/PERMEN-KP/2016. Dalam pedoman tersebut padat tebar udang windu dengan sistem ekstensif polikultur sebanyak 10.000 ekor/hektar dan produktivitas dari budidaya tersebut mencapai 100 sampai $300 \mathrm{~kg} /$ hektar. Sedangkan petambak udang windu di Kelurahan Belawan Sicanang menggunakan padat tebar benur 10.000 ekor/hektar dan produktivitas yang didapat kurang dari $100 \mathrm{~kg} /$ hektar.
Usahatani udang windu di Kelurahan Belawan Sicanang memiliki beberapa kendala seperti kualitas air yang digunakan, perubahan iklim, kualitas benur dan lain - lain. Air yang dipakai oleh petambak berasal dari aliran air dari Sungai Belawan dan Sungai Terjun. Pada saat hujan turun, aliran sungai terjun banyak terdapat sampah - sampah yang berasal dari TPA (Tempat Pembuangan Akhir) Terjun Hamparan Perak. Air sungai menjadi berbau dan berminyak. Kualitas air yang buruk akan menyebabkan udang windu mudah terkena penyakit seperti penyakit White Spot Syndrome Virus (WSSV) (Zulpikar, dkk, 2016). Benur udang windu yang digunakan petambak belum bersertifikat dan diperoleh dari Provinsi Aceh. Menurut petambak di Kelurahan Belawan Sicanang, tingkat kehidupan udang mulai menurun sejak terjadinya Tsunami Aceh.

Usahatani udang windu pasti memiliki risiko dan ketidakpastian. Adanya risiko dalam berusahatani akan menimbulkan dampak negatif terhadap petambak. Petambak sebagai pembuat keputusan dalam berusahatani dapat mengetahui peluang terhadap suatu kejadian ditunjukkan dari risiko (Asaad, dkk, 2019). Peluang kejadian ini dapat ditentukan dari data historis atau pengalaman selama berusahatani. Dengan mengetahui besarnya risiko, para petambak dapat mengambil keputusan yang tepat agar meminimalkan risiko yang terjadi. Penelitian ini bertujuan untuk mengetahui pendapatan dan besarnya risiko yang dihadapi dalam usahatani udang windu di Kelurahan Belawan 
Sicanang Kecamatan Medan Belawan

Kota Medan dari sisi produksi, harga dan pendapatan.

\section{METODE PENELITIAN}

Lokasi penelitian dilakukan di Kelurahan Belawan Sicanang Kecamatan Medan Belawan Kota Medan. Populasi dalam penelitian ini adalah petambak udang windu di Kelurahan Belawan Sicanang. Jumlah populasi dalam penelitian ini adalah 166 petambak. Metode pengambilan sampel dengan cara Simple Random Sampling. Penetapan jumlah sampel menggunakan pendapat Roscoe (1975) dan jumlah sampel yang digunakan dalam penelitian ini sebanyak 30 petambak udang windu. Jenis data yang digunakan adalah data primer dan data sekunder. Data primer diperoleh dari petambak udang dengan melakukan wawancara dengan menggunakan kuesioner dan pengamatan langsung terhadap objek studi. Data sekunder diperoleh dari lembaga - lembaga terkait, seperti Balai Pelatihan dan Penyuluhan Perikanan Medan, Dinas Pertanian Kota Medan, Badan Pusat Statistik dan sumber lainnya.

Metode analisis yang digunakan untuk mengetahui analisis pendapatan, risiko produksi, risiko harga dan risiko pendapatan adalah sebagai berikut :

a. Analisis pendapatan usahatani udang windu mengacu pada Shinta (2011). Analisis pendapatan yang dirumuskan sebagai berikut :

$\mathrm{Pd}=\mathrm{TR}-\mathrm{TC}$

$\mathrm{TR}=\mathrm{Y} . \mathrm{Py}$

$\mathrm{TC}=\mathrm{FC}+\mathrm{VC}$

Keterangan :

$\mathrm{Pd}=$ Pendapatan $(\mathrm{Rp} /$ Musim tanam)

$\mathrm{TR}=$ Penerimaan (Rp/Musim tanam)
$\mathrm{TC}=$ biaya total (Rp/Musim tanam)

$\mathrm{FC}=$ biaya tetap (Rp/Musim tanam)

$\mathrm{VC}=$ biaya tidak tetap $(\mathrm{Rp} /$ Musim tanam)

$\mathrm{Y}=$ produksi udang $(\mathrm{Kg} /$ Musim tanam)

Py $=$ Harga $(\mathrm{Rp} / \mathrm{Kg})$

b. Analisis risiko produksi, harga dan pendapatan usahatani udang windu dilihat dari data produksi, harga dan pendapatan pada musim tanam sebelumnya. Analisis risiko yang dirumuskan menurut Kadarsan (1995) sebagai berikut :

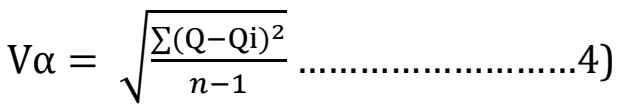

$$
\begin{aligned}
& C V=\frac{\mathrm{V} \alpha}{Q_{i}} \\
& \mathrm{~L}=\mathrm{Qi}-2 \mathrm{~V} \alpha
\end{aligned}
$$

Keterangan :

$\mathrm{V} \alpha=$ simpangan baku (standard deviation)

$\mathrm{Q}$ = hasil produksi ( $\mathrm{kg} / \mathrm{ha})$, harga $(\mathrm{Rp} / \mathrm{kg})$, pendapatan $\mathrm{Rp} / \mathrm{kg}$ ) usahatani tambak udang.

$\mathrm{Qi}=$ hasil produksi rata - rata $(\mathrm{kg} / \mathrm{ha})$, harga rata - rata $(\mathrm{Rp} / \mathrm{kg})$, pendapatan rata - rata usahatani tambak udang $(\mathrm{Rp} / \mathrm{kg})$.

$\mathrm{n}$ = jumlah sampel

$\mathrm{CV}=$ Koefisien Variasi

$\mathrm{L}=$ batas bawah hasil tertinggi

Hubungan antara nilai batas bawah poduksi, harga dan pendapatan (L) dengan nilai koefisien variasi. Apabila nilai $C V \leq 0,5$ maka nilai $L \geq 0$, begitu pula bila $\mathrm{CV}>0,5$ maka nilai $\mathrm{L}<0$. Hal ini menunjukkan: Jika $\mathrm{CV} \leq 0,5$ maka petani terhindar dari risiko dalam melaksanakan usahatani udang windu dan jika CV > 0,5 maka ada peluang risiko bagi petambak dalam melaksanakan usahatani udang windu. 


\section{HASIL DAN PEMBAHASAN}

\section{Pendapatan Usahatani Udang Windu}

Berdasarkan Tabel 1 dapat diketahui bahwa biaya tenaga kerja lebih besar daripada biaya lainnya, pada umumnya tenaga kerja yang digunakan adalah tenaga kerja dalam keluarga. Kegiatan yang membutuhkan waktu lama adalah pengolahan lahan, perbaikan/ perawatan tanggul dan pada saat panen memerlukan lebih dari 2 tenaga kerja luar keluarga. Kegiatan pengolahan lahan seperti pengangkatan lumpur dari dasar tambak dan penggemburan tanah.

Tabel 1. Pengeluaran Usahatani Udang Windu

\begin{tabular}{clr}
\hline No & Jenis Pengeluaran & Biaya (Rp/Musim tanam/Ha) \\
\hline 1 & Penyusutan Peralatan & 79.375 \\
2 & Pajak/Sewa Lahan & 573.160 \\
Total Biaya tetap & 652.536 \\
3 & Benur & 731.077 \\
4 & Pupuk, Obat \& Pakan & 897.405 \\
5 & Tenaga Kerja & 2.214 .304 \\
Total Biaya Tidak Tetap & 3.842 .786 \\
\hline \multicolumn{2}{l}{ Total Biaya } & $\mathbf{4 . 4 9 5 . 3 2 1}$ \\
\hline
\end{tabular}

Sumber : Data primer(diolah), 2020

Biaya pupuk, obat \& pakan terbesar kedua setelah biaya tenaga kerja, pupuk yang digunakan dalam usahatani udang windu adalah pupuk urea, kapur dolomit dan TSP. Pupuk digunakan untuk menambah pakan alami udang. Kapur dolomit untuk memperbaiki pH tanah. Obat yang digunakan pada petambak udang di Kelurahan Belawan Sicanang adalah Saponin, Ursal, Rusbanol, Ton, dan Lodan sedangkan pakan yang digunakan adalah pelet, ikan ruca dan jagung.

Benur yang digunakan oleh petambak udang windu di Kelurahan Belawan Sicanang dari pembenihan udang windu Provinsi Aceh. Petambak mendapatkan benur udang dari pemesanan langsung ke Provinsi Aceh atau supplier yang ada di sekitar Kelurahan Belawan Sicanang. Supplier ini mendapatkan benur dari pembenihan udang Provinsi Aceh. Tempat pembenihan udang terdekat dengan Kota Medan di Kecamatan Pantai Cermin Kabupaten Serdang Berdagai, tetapi di sana benur udang windu tidak ada, pembenihan di Kecamatan Pantai Cermin adalah pembenihan udang vaname. Petambak di Kelurahan Belawan Sicanang mengambil benur dari Provinsi Aceh sejak Tahun 1990-an. Petambak menebar benur udang sebanyak 15.758 ekor/Ha dengan harga per ekor Rp 46. Ukuran benur sekitar PL-10 sampai PL12. Ukuran benur PL-10/ post larva-10 menunjukkan morfologinya sudah seperti udang dewasa. Berdasarkan SNI 01-7252-2006, umur PL-10 adalah 18 hari setelah larva. Benur udang yang didapat petambak dalam kantong plastik. Penebaran benur dilakukan pada pagi hari. Langkah - langkah penebaran benur adalah kantong plastik dibuka, kantong plastik berisi benur diisi air tambak, berbandingan antara air dalam kantong 
plastik dan air tambahan $1: 1$. Kantong plastik didiamkan selama 10-15 menit dan diletakkan di tepi tambak, setelah itu kantong plastik dimiringkan, benur udang akan lepas dengan sendirinya. Biaya lahan yang digunakan untuk berusahatani udang windu adalah biaya sewa atau pajak lahan tersebut. Banyak petambak yang statusnya sewa. Biaya sewa lahan berbeda - beda tergantung lokasi, kesuburan tanah dan keadaan tanggul pada tambak tersebut.

Tabel 2. Pendapatan Usahatani Udang Windu

\begin{tabular}{clcr}
\hline No & \multicolumn{1}{c}{ Penilaian } & \multicolumn{1}{c}{ Satuan } & \multicolumn{1}{c}{ Nilai } \\
\hline 1 & Produksi & Kg/Ha/Musim Tanam & 79,93 \\
2 & Harga & Rp/Kg & 94.869 \\
3 & Penerimaan & Rp/Ha/Musim tanam & 7.534 .276 \\
4 & Total biaya & Rp/Ha/Musim tanam & 4.495 .321 \\
5 & Pendapatan & Rp/Ha/Musim tanam & 3.038 .955 \\
\hline
\end{tabular}

Sumber : Data primer(diolah), 2020

Tabel 2 menunjukkan bahwa udang yang dihasilkan sebanyak 79,93 $\mathrm{kg} / \mathrm{ha} /$ musim tanam. Udang yang dihasilkan berbeda - beda ukuran. Harga jual udang dipengaruhi oleh ukuran udang. Perubahan harga per ukuran udang berkisar Rp. $2.000-13.000 / \mathrm{kg}$. Rata-rata harga jual udang windu yang diterima pertambak adalah Rp. 94.869/kg Pendapatan yang dihasilkan petambak udang di Kelurahan Belawan Sicanang sebesar Rp. 3.038.955/ha/musim tanam. Budidaya udang windu mulai pengolahan lahan sampai panen selama 4 bulan (1 musim tanam). Petambak di Kelurahan Belawan Sicanang bisa melakukan 3 kali musim tanam dalam 1 tahun jika udang yang dibudidayakan tidak terkena penyakit. Jika udang yang dibudidayakan terkena penyakit, dalam 1 tahun petambak bisa melakukan periode tebar benur lebih dari 3 kali. Pada saat udang terkena penyakit akan dilakukan panen dini yang artinya panen dilakukan sebelum umur udang 3 bulan. Usahatani udang windu secara perhitungan usaha menguntungkan sehingga perlu pengembangan usaha untuk kedepannya.

Penelitian Saragih, NS, dkk (2015) di Di Kelurahan Labuhan Deli, Kecamatan Medan Marelan, Kota Medan dimana hasil yang didapat pendapatan terendah yang diterima petambak dalam satu tahun sebesar Rp.5.736.098/MT. Penelitian Utami, R, dkk (2013) di Kecamatan Secanggang Kabupaten Langkat dimana rata-rata pendapatan pada usahatani tambak udang sistem ekstensif sebesar Rp. 4.038.351,19/MT. Pendapatan yang diterima petambak di Kelurahan Labuhan Deli dan Kecamatan Secanggang lebih besar dibandingkan pendapatan yang diterima petambak di Kelurahan Belawan Sicanang. Produksi yang di dapatkan Kelurahan Belawan Sicanang lebih rendah dibandingkan yang didapatkan di Kelurahan Labuhan Deli dan Kecamatan Secangggang.

\section{Risiko Usahatani Udang Windu}

Perhitungan risiko digunakan sebagai pertimbangan petambak dalam mengambil keputusan. 
Tabel 3 Perhitungan Risiko Usahatani Udang Windu

\begin{tabular}{lrrr}
\hline Penilaian & $\begin{array}{c}\text { Risiko Produksi } \\
\text { (Kg/Ha) }\end{array}$ & $\begin{array}{c}\text { Risiko Harga } \\
\text { (Rp) }\end{array}$ & $\begin{array}{r}\text { Risiko Pendapatan } \\
\text { (Rp) }\end{array}$ \\
\hline Rata - rata $\left(\mathrm{Q}_{\mathrm{i}}\right)$ & 79,93 & 94.869 & 3.038 .955 \\
Simpangan Baku $(\mathrm{V})$ & 14,97 & 18.409 & 1.457 .233 \\
Koefisien Variasi $(\mathrm{CV})$ & 0,19 & 0,19 & 0,48 \\
Batas Bawah (L) & 49,99 & 58.051 & 124.489 \\
\hline
\end{tabular}

Sumber : Data primer(diolah), 2020

Perhitungan ini diperoleh dari hasil yang didapatkan pada musim tanam sebelumnya. Pada penelitian ini yang dihitung adalah risiko produksi, harga dan pendapatan. Perhitungan risiko usahatani tambak udang windu di Kelurahan Belawan Sicanang terlihat pada Tabel 3.

Hasil penelitian yang terlihat pada Tabel 3 menunjukkan bahwa nilai simpangan baku risiko produksi pada usahatani udang windu adalah 14,97. Nilai simpangan baku dapat diartikan sebagai tingkat risiko produksi yang dihadapi oleh petambak udang windu. Nilai tersebut menunjukkan bahwa tingkat risiko produksi yang dihadapi petambak udang pada setiap periode dimasa yang akan datang. Hasil penelitian Rahayu dkk (2020) simpangan baku risiko produksi udang windu di Kecamatan Pasir Sakti Kabupaten Lampung Timur sebesar 82,93. Simpangan baku risiko produksi usahatani udang windu di Kelurahan Belawan Sicanang lebih kecil dibandingkan daripada di Kecamatan Pasir Sakti Kabupaten Lampung.

Nilai koefisien variasi yang didapat dalam penelitian ini adalah 0,19. Artinya untuk setiap $1 \mathrm{~kg}$ yang diperoleh petambak akan menghasilkan risiko sebesar 0,19 kg. Semakin besar nilai koefisien variasi yang didapatkan maka semakin besar pula risiko yang dihadapi. Nilai batas bawah yang didapat adalah 49,99 kg. Angka tersebut menunjukkan bahwa batas minimal produksi yang harus dihasilkan petambak dimasa mendatang. Karena dalam penelitian ini nilai $\mathrm{CV}<0,5$ dan nilai $\mathrm{L}>0$ maka usaha tambak udang di setiap musim tanamnya akan terhindar dari kerugian risiko produksi. Hal ini sesuai dengan penelitian Rahayu dkk (2020) yang dilakukan di Kecamatan Pasir Sakti menunjukkan nilai koefisien variasi yang didapat lebih besar dari nol $(0,35>0)$ dan nilai batas bawah yang didapat 56,31 $>0$ artinya usaha udang windu yang dijalankan dapat terhindar dari kerugian Usahatani udang windu yang dibudidayakan petambak di Kelurahan Belawan Sicanang terhindar dari kerugian berdasarkan nilai $\mathrm{CV}$ dan $\mathrm{L}$ pada risiko produksi. Jumlah produksi udang windu yang dihasilkan petambak di Kelurahan Belawan Sicanang masih dibawah standar berdasarkan Peraturan Menteri Kelautan dan Perikanan Republik Indonesia Nomor 75/PERMENKP/2016. Jumlah produksi yang tidak mencapai standar disebabkan beberapa hal yaitu udang terkena penyakit, kualitas benur, kualitas air, curah hujan tinggi, serangan hama dan pecah tanggul.

Sumber risiko produksi yang memiliki pengaruh besar dalam 
menjalankan usahatani udang windu di Kelurahan Belawan Sicanang adalah penyakit White Spot Syndrome Virus (WSSV). Penyakit ini dapat menyebabkan kematian massal. Penyakit ini dapat menular dengan udang lainnya (Mahardika, K, dkk, 2004). Hasil penelitian Rahma, dkk (2014), White Spot Syndrome Virus merupakan penyakit yang penularannya sangat cepat dan menyebabkan kematian 100 persen dalam waktu 3 - 10 hari mulai timbul gejala. Gejala jika udang windu terkena penyakit ini adalah udang berenang di tepi tambak, penurunan respon pakan, tidak responsif, terdapat bintik putih dan tubuh kemerahan.

Harga udang windu naik jika permintaan udang windu meningkat, biasanya permintaan udang windu meningkat menjelang hari raya Imlek. Pada saat masa pandemi Covid-19 ini, harga udang windu mengalami penurunan dari Rp. 7.000 sampai Rp. 10.000 per kilogramnya. Harga jual rata - rata udang windu di Kelurahan Belawan Sicanang adalah Rp 94.869/kg. Harga paling rendah yang mungkin diterima oleh petambak pada usahatani udang adalah Rp 58.051/kg dilihat dari nilai batas bawah. Koefisien variasi risiko harga pada usahatani udang windu adalah 0,19 artinya untuk Rp 1 yang diterima petambak akan menghasilkan risiko sebesar Rp 0,19. Dalam penelitian ini, nilai koefisien variasi yang diperoleh kurang dari 0,5 dan nilai batas bawahnya lebih dari 0 maka usahatani udang windu akan terhindar dari kerugian disisi risiko harga.

Pendapatan yang diterima petambak Kelurahan Belawan Sicanang dari usahatani udang windu adalah Rp.
3.038.955. Nilai simpangan baku yang didapat sebesar Rp. 1.457.233, nilai ini menunjukkan bahwa fluktuasi pendapatan atau risiko yang harus dihadapi petambak. Koefisien variasi (CV) risiko pendapatan sebesar 0,48 artinya untuk Rp 1 yang diterima petambak akan menghasilkan risiko sebesar Rp 0,45. Nilai koefisien variasi yang diperoleh kurang dari 0,5 dan nilai batas bawahnya lebih dari 0 maka usahatani udang windu akan terhindar dari kerugian disisi risiko pendapatan. Risiko pendapataan lebih tinggi dibandingkan dengan risiko produksi dan harga. Risiko pendapatan dipengaruhi oleh risiko produksi dan harga. Hal ini sejalan dengan penelitian Misqi (2020) yang mengatakan bahwa risiko pendapatan berbanding lurus dengan risiko produksi. Apabila jumlah produksi yang didapat sedikit sedangkan biaya produksi tetap maka pendapatan yang didapat akan berkurang..

\section{SIMPULAN}

Hasil penelitian menunjukkan bahwa penerimaan yang diterima petambak lebih besar daripada total biaya yang dikeluarkan. Artinya usahatani udang windu yang dijalankan menguntungkan. Berdasarkan nilai koefisien variasi (CV) dan nilai batas bawah (L) risiko produksi, harga dan pendapatan, usahatani udang windu di Kelurahan Belawan Sicanang akan terhindar dari kerugian.

\section{DAFTAR PUSTAKA}

Asaad, Andi Indra Jaya. Ruzkiah Asaf. Admi Athirah \& Erna Ratnawati (2019). Analisis Resiko Produksi Dan Pendapatan Pada Usaha Budi 
Daya Tambak Udang Windu Di Kabupaten Kotabaru, Provinsi Kalimantan Selatan. Jurnal Sosial Ekonomi Kelautan dan Perikanan. 14 (2) : 125 - 134.

Badan Pusat Statistik. (2017). Provinsi Sumatera Utara Dalam Angka 2017. Badan Pusat Statistik Provinsi Sumatera Utara.

Badan Pusat Statistik. (2018). Kota Medan dalam Angka 2018. Badan Pusat Statistik Kota Medan.

Kadarsan, H.W. (1995). Keuangan Pertanian dan Pembiayaan Perusahaan Agribisnis. Cetakan Kedua. PT. Gramedia Pustaka Utama. Jakarta.

Kantor Lurah Belawan Sicanang. (2019). Profil Kelurahan Belawan Sicanang. Kantor Kelurahan Belawan Sicanang.

Kementerian Kelautan dan Perikanan. (2017). Peraturan Menteri Kelautan Dan Perikanan Republik Indonesia No 75/PERMENKP/2016. Jakarta.

Mahardika K, Zafran dan I. Koesharyani. (2004). Deteksi White Spot Syndrome Virus (WSSV) Pada Udang Windu (Penaeus monodon) di Bali dan Jawa Timur Menggunakan Metode Polymerase Chain Reaction (PCR). Jurnal Penelitian Perikanan Indonesia, 10 (1): 55-60.

Misqi, Raini Nurul \& Tuti Karyani (2020). Analisis Risiko Usahatani Cabai Merah Besar (Capsicum annuum L) Di Desa Sukalaksana Kecamatan Banyuresmi Kabupaten Garut. Jurnal Pemikiran Masyarakat Ilmiah Berwawasan Agribisnis (MIMBAR AGRIBISNIS). 6(1) : 6576

Rahma, H. N., S. B. Prayitno, dan A. H. C. Haditomo. (2014). Infeksi White Spot Sindrome (WSSV) Pada Udang Windu Yang Dipelihara Pada
Salinitas Media yang Berbeda. Jurnal Of Agriculture Management and Technologi. 3(3) : 25-34

Rahayu, Yuni Astika, Fembriarti Erry Prasmatiwi, Ani Suryani (2020). Pendapatan dan Risiko Usaha Tambak Udang Windu Dan Udang Vaname Di Kecamatan Pasir Sakti Kabupaten Lampung Timur. Jurnal Ilmu - Ilmu Agribisnis (JIIA). 8(2) : $287-294$.

Roscoe, J. T. (1975). Fundamental Research Statistics For The Behavioural Sciences. (2nd ed.) New York: Holt Rinehart \& Winston.

Saragih, Nani Sura,. Ketut Sukiyono \& Indra Cahyadinata (2015). Analisis Resiko Produksi Dan Pendapatan Budidaya Tambak Udang Rakyat Di Kelurahan Labuhan Deli, Kecamatan Medan Marelan, Kota Medan. Jurnal AGRISEP. 14 (1) : 39 $-52$.

Shinta A. (2011). Ilmu Usahatani. Malang. Ub Press.

Soekartawi, dkk. (1993). Risiko dan Ketidakpastian dalam Agribisnis. PT Raja Grafindo Persada : Jakarta.

Utami, Rizki. Tavi Supriana, Rahmanta Ginting. (2014). Analisis FaktorFaktor yang Mempengaruhi Produksi Tambak Udang Sistem Alam dan Sistem Intensif (Studi Kasus: Kecamatan Secanggang, Kabupaten Langkat). Jurnal of Agriculture and Agribusiness Socioeconomics. 3(2).

Zulpikar, teuku Reza Ferasyi, Sugito. (2016). Analisis Pengaruh Faktor Kualitas Air Terhadap Resiko Penyakit White Spot Syndrome Virus (WSSV) Pada Udang Vannamei (Litopenaeus Vannamei) Di Kecamatan Peudada Kabupaten Bireuen. Jurnal Ilmu - Ilmu Perairan, Pesisir dan Perikanan (DEPIK). 5(1) : 1-6 